\title{
Journal of Education
}

\section{ISSN Online: 2616-8383}

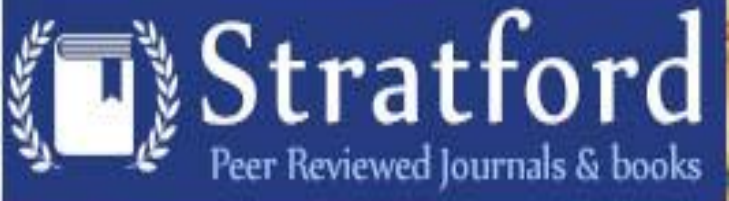

Impact of Poverty on Quality of Education in Haiti

Dube Moffatt Gedro, Davison Bartel Hartman \& Lindor Suárez 


\title{
Impact of Poverty on Quality of Education in Haiti
}

\author{
${ }^{1 *}$ Dube Moffatt Gedro, ${ }^{2}$ Davison Bartel Hartman \& ${ }^{3}$ Lindor Suárez \\ ${ }^{1}$ PhD Student, University of Haiti \\ ${ }^{2}$ Lecturer, University of Haiti \\ ${ }^{3}$ Lecturer, University of Haiti \\ *Email of the corresponding author: moffattedro @ gmail.com
}

How to cite this article: Gedro, D., M., Hartma, D., B., \& Suárez, L. (2021). Impact of Poverty on

Quality of Education in Haiti. Journal of Education 4 (7), 1-9. https://doi.org/10.53819/810181025019

\begin{abstract}
Education is among the critical needs besides the food, shelter and clothing in modern life. Quality education is an effective tool for minimizing poverty and joblessness, enhancing health and dietary standards, and attaining lasting growth. Hence, the study sought to determine the impact of poverty on the quality of education in Haiti. The study was a literature review based. The conclusions were based on reviewing previous studies. The study findings indicated that poverty influences the quality of education. The study noted the significance of education in developing countries could not be overstated. Quality education can be the catalyst needed to pull families and communities out of the cycle of poverty. Knowledge gives children the power to dream of a better future and the confidence required to pursue a complete education, which will help generations to come. The study further ascertained that education makes a significant difference for adults, particularly in day-to-day life, including nutrition, healthcare and gender equity. The poverty levels are potent in influencing the quality of education that the students will receive in the long run. The study recommended adequate mechanisms to ensure the government support children from a poor background. Addressing the academic difficulties children from deprived families will undoubtedly need a broader and bolder method to education policy than the current initiatives to reform schools. The government should make sure that school-age children are enrolled right into compulsory and free primary education. Given that education is a powerful device for minimizing poverty and joblessness, enhancing health and dietary requirements, and attaining sustainable advancement, the Haitian government must inject much more revenue in the education sector, mainly for the poor children to obtain a quality education. The government is required to make sure all learners within its nation have access to education both in rural and in metropolitan places.
\end{abstract}

Keywords: Poverty, Quality of Education, Children, Haiti

https://doi.org/10.53819/810181025019 
Stratford Peer Reviewed Journals and Book Publishing

Journal of Education

Volume 4||Issue 7 ||Page 1-9 ||October |2021|

Email: info@stratfordjournals.org ISSN: 2616-8383

\subsection{Background of the Study}

Poverty can be best defined as the absence or deficiency of money to satisfy fundamental food, clothing and shelter (Thorbecke, 2018). Poverty remains a stubborn fact of life, even in rich countries like Haiti. In particular, the poverty of the children has been a continuing concern. In 1989, the Haiti House of Commons voted unanimously to eliminate poverty among Haitian children by 2000 (Rutkowski, Rutkowski, Wild \& Burroughs, 2018). However, the reality is that, in 2015 , one of every six children still lived in poverty. Not only have we been unsuccessful at eradicating child poverty, but over the past decade, the inequity of family incomes in Haiti has grown and for some families, the depth of poverty has increased as well. Haiti research confirms poverty's negative influence on student behaviour, achievement and retention in school (Dube, Moffatt, Davison \& Bartels, 2018). This poverty can be measured in monetary terms according to the month-to-month or annual expenditure of an offered individual. It's a broad social issue that cuts across countries, races, places, society and religion. It has been in presence since the times of development of the human race on earth. Illiteracy plagues virtually $40 \%$ of the adult population (Ross \& Anderson, 2020). Around $75 \%$ of educators do not have any kind of training or qualifications. Many children in Haiti spend less than 4 years in school and 35\% of them never learn to read. Schools in Haiti are sometimes overcrowded and typically do not have the resources to offer an excellent education (Gedro \& Hartman, 2019). Overcrowded classes, untrained educators and the absence of supplies make it difficult to learn. In recent years, the Canadian government has actually made considerable gains in improving learning institutions.

Education is essential to transformation. It plays an essential role in bringing social communication and economic success. The educational sector generates the smallest affordable overall rate in the education realm of the Western Hemisphere (Bellegarde-Smith, 2018). Haiti's literacy rate of about $61 \%$ (64.3\% for males and $57.3 \%$ for females) is below the $90 \%$ average literacy rate for Latin American and Caribbean countries. Most Haitians do not have access to quality education, a prerequisite for sustained social and economic growth. Haiti is in position 177 out of 186 for national with low literacy level (Bailey, 2019). Just 76 percent of learners in Haiti are registered in primary institutions, among the smallest enrollment rates worldwide. Equitable accessibility to materials that could disrupt generational poverty like quality education, electricity, basic health care, clean water, and secure housing is beyond reach for most of Haiti's population.

Children born right into severe poverty are less likely to get an education considering that they cannot go to learning institutions if their parents cannot afford the charges. With $78 \%$ of the population surviving less than $\$ 2$ a day and 54\% living on less than $\$ 1$ a day, even reduced school fees are tough to pay. Poverty has a severe impact on learner efficiency. Research has revealed that learners in poverty are listed below the average mark at much bigger rates and generally have poor or ordinary grades (Jensen, 2019). Academic shortages offer severe handicaps for learners in hardship. There are several aspects included which figure in learners' achievement: health and nutrition, vocabulary, effort, hope and development mindset, cognition, connections, and distress. Learners with hardship are prone to be exposed to food with little or no dietary value that impacts cognitive operating and consequently, has negative impacts on scholastic attainment (Ross and Anderson, 2020). Inadequate vocabulary likewise impacts educational capability and direct exposure to language is less likely in low socioeconomic instances. Learners fail to attain academically because of the low socioeconomic condition associated with depressive signs.

https://doi.org/10.53819/810181025019 
Stratford Peer Reviewed Journals and Book Publishing

Journal of Education

Volume 4||Issue 7 ||Page 1-9 ||October |2021|

Email: info@stratfordjournals.org ISSN: 2616-8383

In Haiti, private schools dominate $80 \%$ of the learning institutions in primary education and $75 \%$ of the institutions in secondary education are private schools (Hebblethwaite, 2020). There are two types of private schools: confessional institutions and common institutions. A majority of $66 \%$ of the private schools are confessional. The confessional schools are separated into catholic and also protestant institutions. Catholic schools are in the city and rural locations. At the same time, protestant schools are generally in rural locations, where the inadequate residents reside. Distinctions between private schools are substantial. A little team of elite private schools are at the top, supplying the good education, public schools lie in the middle array and the vast bulk of private schools are found at the down of the scale. Haiti home survey information shows virtually one-half of inadequate learners have no accessibility to main education and 90 percent of family heads without education are poor, and three-quarters of non-poor learners are enlisted in key education and 90 percent of home heads with higher education are not bad (Herz, 2018). Destitution brings about unequal access to learning that results in inequality and minimal effect of development on decreasing poverty.

2010 Haiti earthquake accelerated the currently constrained criteria on Haiti's academic sector by damaging infrastructure and displacing 50-90\% of the learners, relying on place (Manigat and French, 2020). Canada, France manage international private schools, US and church-run institutions educate $90 \%$ of learners. Haiti has 15200 primary schools, whereby $90 \%$ are nonpublic and operated by locals, religious institutions or NGOs (Jean-Pierre, 2020). Ministry of education gives extremely little capital to sustain public education thereby the private segment has become as a substitute for governmental public financial investment in learning. Furthermore, the ministry is restricted in its capability to enhance the quality of learning in Haiti it also plays a considerable role in the decision of curriculum components, guidelines, recognition of degrees and certificates, and assessments. The ministry does not sufficiently divide the roles of administration and plans to make from the features of management. There is no solid and independent planmaking body.

The Education database in the country is being organized to advance standard information on the nation's 200,000 instructors. Those registered in the system will be given a training license and given two years to verify they have the required qualifications. Furthermore, information on the nation's 20,000 schools is being caught and institution identity card will certainly be given, from which period each college has two years to satisfy specific set criteria (Chubb \& Moe, 2019). Failing to satisfy these standards will suggest that the institution will not be licensed to operate or be qualified for government aid. These two measures are the existing concerns of the ministry. In accordance with the nationwide information, in 2014-2015 education costs was 19.8\% of Haiti's overall state investing which stood for $9 \%$ of the gross domestic product. Haiti has made available UIS registration information for 2011/2012 (Eras, Joseph, Franco, Leng \& Pierre, 2016). The ministry of education is boosting its data system with technical and financial assistance from companions like IDB, UNESCO, and AECID to provide upgraded education types annually. Thus, the study was focused on examining the impact of poverty on educational outcomes for children in Haiti. 
Stratford Peer Reviewed Journals and Book Publishing

Journal of Education

Volume 4||Issue 7 ||Page 1-9 ||October |2021|

Email: info@stratfordjournals.org ISSN: 2616-8383

\subsection{Literature Review}

Education is among essential requirements together with food, shelter and clothing in our lives today. The Constitution of India has given the right to cope with dignity and honor to each resident. To guarantee fundamental rights, the government has been using several actions. Popular amongst them are the universalization of mandatory and complimentary paramount education to all children of school-age. Moreover, right to adhere to and propagate the religion and faith of one's own free will and decision. While the official education is an instrument for guaranteeing the right to live with purpose and recognize the later to adhere to and circulate the faith of one's very own free will is a pre-requisite setting in many religious-secular countries like India. Education is a robust mechanism for decreasing hardship and joblessness, boosting health and dietary level, and attaining sustainable growth (Salem, 2020). Despite substantial progress over the past couple of years, Haiti is battling to supply free and best quality primary schooling, conforming to the Millennium Development Goal of universal primary education.

Destitution remains a persistent fact of life even in wealthy nations like Haiti. Lindor and Suárez (2021) conducted a study to analyze the impact of extreme poverty, violence, criminal offense and kidnapping on the academic performance and psychological health of high school and undergraduate students in public schools and universities found in Port-au-Prince Haiti. It was a qualitative study of a deductive type and a semi-structured interview to gather the information and attract important conclusions. The outcomes show that extreme poverty, violence, criminal offense and kidnapping influence the academic performance and psychological health of high school and undergraduate students in public schools and universities found in Port-au-Prince Haiti.

Further, Gordon, Nandy, Pantazis, Townsend and Pemberton (2018) examined the effect of poverty on the performance of the students. The study adopted the descriptive research design. The target population included teachers and students within the primary schools in Pakistan. The study results showed that poverty is one of the key determinants that influence students' performance. Bonanno, Romero and Klein (2020) indicated that poverty influence the performance of students in Canada. Educational results are among the vital places affected by family members' earnings. Young people from low-income backgrounds often begin learning currently behind their counter parts who originate from even more affluent households, as shown in actions of institution preparedness. The occurrence, depth, period and timing of destitution all affect children educational achievement, in addition to community attributes and social connections. Nonetheless, both Canadian and worldwide interventions have revealed that the impacts of hardship can be reduced by making use of lasting interventions. Doctors and family physician have several possibilities to affect preparedness for institution and instructional success in primary care settings.

Azevedo (2020) performed a research to take a look at the results of poverty on learning. Several aspects contribute to a community becoming impoverished such as deindustrialization, high joblessness cases, untreated psychological health, and terrible crimes. Impoverished communities and city face several issues. These concerns consist of run-down housing, lack of accessibility to professional services, and most significantly learning. The learning is inferior for a number of reasons; learners are turning up to school with many troubles that the instructors are incapable to account for through instruction. The school facilities deal with structural inadequacies which have been shown to have an effect on the quality of guideline. The instructors in the institutions, while certified, are often times not sustained by school management. Institution managers are hectic with

https://doi.org/10.53819/810181025019 
Stratford Peer Reviewed Journals and Book Publishing

Journal of Education

Volume 4||Issue 7 ||Page 1-9 ||October||2021|

Email: info@stratfordjournals.org ISSN: 2616-8383

their very own problems in identifying what areas to assign their minimal budget. Destitution is a vast and intricate concern that afflicts communities in an apparently unlimited cycle. Nevertheless, collaborating to locate reliable means of addressing concerns caused by poverty, the future can come to be a more vibrant for American youth growing up in poor communities.

Poverty is a significant factor to the falling short academic performance of learners in the USA. Reduced socioeconomic status influences physical wellness, mind development, instructional achievement, self-esteem, and self-efficacy. Because of the fact that $20 \%$ of youngsters in the United States are categorized as living in destitution, the effect of these numbers develops a tremendous pressure on the public educational system. Teachers are currently dealing with high varieties of learners who are malnourished, have poor hygiene skills, and little to no adult involvement in their kid's growth and learning (Pigozzi, 2020). With little to no scholastic modeling, the vacuum cleaner hardship creates brings about the growth and suffusion of generational destitution. The damaging results of poverty can have on the advancement of young learners and the difficulties it presents to their education and future.

Poverty which forms a detailed culture and way of life is a growing issue in the USA (Berliner, 2019). The number of Americans staying in hardship is constantly escalating. Poverty indicates the level to which an individual does without resources. Resources can consist of monetary, emotional, mental, spiritual, and physical resources and support group, connections, good example, and knowledge of covert policies. Poverty directly influences scholastic success due to the lack of resources available for learner success (VanTassel-Baska, 2018). Low accomplishment is carefully associated with absence of resources, and various researches have actually recorded the relationship between low socioeconomic condition and reduced success. A number of methods exist to aid teachers in shutting the poverty achievement gap for learners.

Although education is a right, it still continues to be a remote dream for a number of India's children where knowledge is poor. It is clear that it is not nearly enough to make laws; they need to be augmented by even more initiatives. Education needs to come to all if democracy is to succeed (Apple, 2020). Many communities and groups like disadvantaged castes and women have actually been traditionally excluded from learning. Devolution of powers is incredibly important to make learning available to youngsters. The focus is appropriately attracted to the effects of destitution on children's education. As a teacher, one is constantly warned of the academic downsides and disruptions inadequate learners experience due to absence of economic stability and social security (SmithBattle, 2017). Unless we have a strong and widely offered state welfare tool, the learning of the working class kids will continue to be given up. In all this, social worth's and pressures likewise take a specifically serious toll. The willful complicity of the ruling castes and classes is amply obvious as their dominance is derived from keeping economic and social status quo. So the effects of all these research for formulation of effective anti-poverty plan and proper education system in India.

Presently U.S. plans initiatives to enhance the U.S. education sector, involving no kid left behind, test-based evaluation of instructors, and the promotion of competition are misguided due to the fact that they either deny or ready to the side a basic body of proof recording learners from disadvantaged families typically execute less well in school than those from more advantaged families (Cochran-Smith, Piazza \& Power, 2019). Because these plan initiatives do not straight attend to the instructional obstacles experienced by deprived learners, they have contributed little

https://doi.org/10.53819/810181025019 
Stratford Peer Reviewed Journals and Book Publishing

Journal of Education

Volume 4||Issue 7 ||Page 1-9 ||October||2021|

Email: info@stratfordjournals.org ISSN: 2616-8383

and are not likely to add a lot in the future to elevating total learner attainment or to decreasing attainment and instructional achievement gaps in between advantaged and disadvantaged learners. Furthermore, such plans have the possible to do serious harm. Resolving academic difficulties encountered by learners from disadvantaged households will certainly need wider and bolder method to education plan than the recent initiatives to reform schools.

Moreover, a study was conducted by Ferguson, Bovaird and Mueller (2020) to determine the impact of poverty on educational outcomes for children in Canada. The study results established that poverty influences the education outcome of the children in Canada. The persistent socioeconomic disadvantage damages the life outcomes of many Canadian children. The study showed associations between low income and psychiatric disorders, social and academic functioning and chronic physical health problems. The study concluded that Canada has developed systematic measures that have enabled us to track the impact of various child, family and community factors on children's well-being. The National Longitudinal Survey of Children and Youth (NLSCY) developed by Statistics Canada, Human Resources Development Canada and a number of researchers across the country, was started in 1994 with the intention of following representative samples of children to adulthood. The study also concluded that poverty is one of the critical factors that influence the performance of the students in schools.

\subsection{Research Findings and Discussion}

Based on the literature reviewed, it is evidenced that poverty influences the quality of education. The study discovered that poverty negatively affected education. A lot of the learning institutions in Haiti are overcrowded and additionally, they do not have the required reading and learning resources for the learners to acquire the preferred quality learning. Haiti is in position 177 out of 186 globally for nationwide costs on the education market. Furthermore, about 76 percent of learners in Haiti are enlisted in primary school, which is one of the lowest enrollment rates in the entire globe. The study noted that poverty brings about unequal access to education, resulting in inequality and minimal development on poverty reduction. Haiti's government has put access to quality education at the top of its plan program and announced 12 policy measures to stabilize and enhance governance and quality in the education system. The effects of poverty on children are wide-reaching and can lead to lifelong struggles, especially when young people don't receive complete educations. Poverty and education are inextricably linked because people living in poverty may stop going to school to work, which leaves them without the literacy and numeracy skills they need to further their careers. Their children, in turn, are in a similar situation years later, with little income and few options but to leave school and work. The study noted the significance of education in developing countries could not be overstated. Education can be the catalyst needed to pull families and communities out of the cycle of poverty. Knowledge gives children the power to dream of a better future and the confidence required to pursue a complete education, which will help generations to come. The study further established that education also makes a significant difference for adults, particularly in day-to-day life, including nutrition, healthcare and gender equity. When adults learn, they become role models to their children, who also wish to learn.

https://doi.org/10.53819/810181025019 
Stratford Peer Reviewed Journals and Book Publishing

Journal of Education

Volume 4||Issue 7 ||Page 1-9 ||October |2021|

Email: info@stratfordjournals.org ISSN: 2616-8383

\subsection{Conclusion}

The study concluded that poverty influences the quality of education. Poverty has an adverse result on learner achievement and have revealed that learners in poverty are below grade level at much higher rates and typically have bad or ordinary scores. Learners in poverty are more likely to be exposed to food with little or no nutritional worth, which results in cognitive functioning and has negative impacts on academic success. The distinctions between private schools are massive and need to be addressed. Furthermore, the study concluded that poverty leads to unequal access to education, which leads to inequality and restricted effect of growth on poverty decrease. Haiti's government is required to place access to quality education at the top of its plan program and completely fund it. The adverse effects of poverty can have on the advancement of young learners and the obstacles it presents to their education and future. The study noted the significance of education in developing countries could not be overstated. Education can be the catalyst needed to pull families and communities out of the cycle of poverty. Knowledge gives children the power to dream of a better future and the confidence required to pursue a complete education, which will help generations to come. The study further ascertained that education makes a significant difference for adults, particularly in day-to-day life, including nutrition, healthcare and gender equity. When adults learn, they become role models to their children, who also wish to learn. Poverty directly impacts academic achievement as a result of the lack of resources offered for learner success. Low attainment is precisely correlated with a lack of resources, and numerous researches have documented the connection between reduced socioeconomic status and scanty success. The poverty levels are potent in influencing the quality of education that the students will receive in the long run.

\section{Recommendations}

The study recommended adequate mechanisms to ensure the government support children from a poor background. Addressing the academic difficulties children from deprived families will undoubtedly need a broader and bolder method to education policy than the current initiatives to reform schools. The government should make sure that school-age children are enrolled right into compulsory and free primary education. Given that education is a powerful device for minimizing poverty and joblessness, enhancing health and dietary requirements, and attaining sustainable advancement, the Haitian government must inject much more revenue in the education sector, mainly for the poor children to obtain a quality education. The government is required to make sure all learners within its nation have access to education both in rural and in metropolitan places. The study noted the significance of education in developing countries could not be overstated. Education can be the catalyst needed to pull families and communities out of the cycle of poverty. Knowledge gives children the power to dream of a better future and the confidence required to pursue a complete education, which will help generations to come. Accessibility to fundamental needs should be made inexpensive to all people in order to enable parents to sustain the education of their children. 


\section{REFERENCES}

Apple, M. W. (2020). Democratic education in neoliberal and neoconservative times. Journal of International Studies in Sociology of Education, 21(1), 21-31. https://doi.org/10.1080/09620214.2011.543850

Bonanno, G. A., Romero, S. A., \& Klein, S. I. (2020). The temporal elements of psychological resilience: An integrative framework for the study of individuals, families, and communities. Psychological Inquiry, 26(2), 139-169. https://doi.org/10.1080/1047840X.2015.992677

Bray, M. (2020). Decentralization of education: Community financing (Vol. 36). World Bank Publications.

Chubb, J. E., \& Moe, T. M. (2019). Politics, markets, and America's schools. Brookings Institution Press.

Cochran-Smith, M., Piazza, P., \& Power, C. (2019, January). The politics of accountability: Assessing teacher education in the United States. In The Educational Forum (Vol. 77, No. 1, pp. 6-27). Taylor \& Francis Group.

Dube, A., Moffatt, M., Davison, C., \& Bartels, S. (2018). Health outcomes for children in Haiti since the 2010 earthquake: a systematic review. Prehospital and disaster medicine, 33(1), 77-88. https://doi.org/10.1017/S1049023X17007105

Eras, A. C., Joseph, N., Franco, L., Leng, P., \& Pierre, G. (2016). The world bank's education forall phase II in Haiti case study. INNOVA Research Journal, 1(2), 10-27. https://doi.org/10.33890/innova.v1.n2.2016.9

Ferguson, H. B., Bovaird, S., \& Mueller, M. P. (2020). The impact of poverty on educational outcomes for children. Paediatrics \& child health, 12(8), 701-706. https://doi.org/10.1093/pch/12.8.701

Gedro, J., \& Hartman, L. P. (2019). Education as a response to NHRD gaps in developing economies: A case study of l'Ecole de Choix/The school of choice (Haiti), as critical national human resource development. Journal of Human Resource Development Quarterly, 27(1), 67-94. https://doi.org/10.1002/hrdq.21220

Gordon, D., Nandy, S., Pantazis, C., Townsend, P., \& Pemberton, S. A. (2018). Child poverty in the developing world. Policy Press.

Hebblethwaite, B. (2020). French and underdevelopment, Haitian Creole and development: Educational language policy problems and solutions in Haiti. Journal of Pidgin and Creole Languages, 27(2), 255-302. https://doi.org/10.1075/jpcl.27.2.03heb

Herz, B. (2018). Letting girls learn: Promising approaches in primary and secondary education (Vol. 133). World Bank Publications.

Jean-Pierre, M. (2020). The Education System of Haiti: History, Challenges, and Perspectives. Journal of The Education Systems of the Americas, 6(2) 1-26. https://doi.org/10.1007/9783-319-93443-3_33-1 
Lindor, M., \& Suárez, M. C. (2021). Extreme poverty, violence and inclusive education in Haiti: Student performance analysis from the multifactorial approach. Cultura, Educación y Sociedad, 12(1), 19-36. https://doi.org/10.17981/cultedusoc.12.1.2021.02

Michalski, J. H., Cunningham, T., \& Henry, J. (2017). The diversity challenge for higher education in Canada: The prospects and challenges of increased access and student success. Humboldt Journal of Social Relations, 3(7), 66-89.

Noguera, P. A. (2019). The trouble with black boys: And other reflections on race, equity, and the future of public education. John Wiley \& Sons.

Pigozzi, M. J. (2020). Education in emergencies and for reconstruction: A developmental approach. New York: Unicef.

Prou, M., Barrows, E., Dejean, Y., Faraclas, N., Fort, H. S., Fouron, G., \& Zéphir, F. (2018). The Haitian Creole language: History, structure, use, and education. Lexington Books.

Ross, A., \& Anderson, D. L. (2020). Nutrition and its effects on academic performance how can our schools improve. Michigan: At Northern Michigan Undersity.

Rutkowski, D., Rutkowski, L., Wild, J., \& Burroughs, N. (2018). Poverty and educational achievement in the US: A less-biased estimate using PISA 2012 data. Journal of Children and Poverty, 24(1), 47-67. https://doi.org/10.1080/10796126.2017.1401898

Salem, H. S. (2020). Digitization of the health and education sectors in the Palestinian society, in view of the United Nations sustainable development goals. In Digitalization and Industry 4.0: Economic and Societal Development (pp. 53-89). Springer Gabler, Wiesbaden. https://doi.org/10.1007/978-3-658-27110-7_4

Salmi, J. (2020). Equity and quality in private education: The Haitian paradox. Compare: $A$ Journal of Comparative and International Education, 30(2), 163-178. https://doi.org/10.1080/03057920050034101

Schnotz, W., Picard, E., \& Hron, A. (2018). How do successful and unsuccessful learners use texts and graphics?. Learning and Instruction, 3(3), 181-199. https://doi.org/10.1016/0959$\underline{4752(93) 90003-\mathrm{I}}$

SmithBattle, L. (2017). "I wanna have a good future": Teen mothers' rise in educational aspirations, competing demands, and limited school support. Journal of Youth \& Society, 38(3), 348-371. https://doi.org/10.1177/0044118X06287962

Thorbecke, E. (2018). Multidimensional poverty: conceptual and measurement issues. In The many dimensions of poverty (pp. 3-19). Palgrave Macmillan, London. https://doi.org/10.1057/9780230592407_1

Tsymbal, S. (2018). Gamified Training Sessions As Means Of Enhancing Students'motivation In Learning English. Psychological Journal, 4(7), 151-161. https://doi.org/10.31108/1.2018.7.17.10

VanTassel-Baska, J. (2018). The role of the family in the success of disadvantaged gifted learners. Journal for the Education of the Gifted, 13(1), 22-36. https://doi.org/10.1177/016235328901300103 